\title{
New data on the fauna of Heteroceridae (Coleoptera) of the Republic of Khakassia (Eastern Siberia)
}

\author{
Alexey S. Sazhnev', Sergey V. Dragan ${ }^{1,2}$ \\ I Papanin Institute for Biology of Inland Waters of the Russian Academy of Sciences, 152742, Borok, \\ Yaroslavl Region, Russia \\ 2 Katanov Khakas State University, Lenin av. 90, 695000, Abakan, Republic of Khakassia, Russia \\ Corresponding author: Alexey S. Sazhnev (sazh@list.ru)
}

Academic editor: R. Yakovlev | Received 11 May 2020 | Accepted 5 June 2020 | Published 6 November 2020

http://zoobank.org/8B0109A5-2170-4E64-8BD2-157FEDE286E5

Citation: Sazhnev AS, Dragan SV (2020) New data on the fauna of Heteroceridae (Coleoptera) of the Republic of Khakassia (Eastern Siberia). Acta Biologica Sibirica 6: 399-406 https://doi.org/10.3897/abs.6.e54155

\begin{abstract}
The recent status of the family Heteroceridae in Siberia is discussed and the main references are given. From ten species of the Heteroceridae, which have been reported for the fauna of Siberia, only one species Heterocerus parallelus Gebler, 1830 was previously recorded in southern Khakassia. Here we presented six species from two genera of the family Heteroceridae (Coleoptera), which we collected in the Republic of Khakassia (Eastern Siberia, Russia). We recorded five species (Augyles interspidulus (Charpentier, 1979), Heterocerus fenestratus (Thunberg, 1784), H. fossor Kiesenwetter, 1843, H. fusculus Kiesenwetter, 1843, and H. obsoletus Curtis, 1828) in Khakassia for the first time. We collected the material in Abakan River valley (Abakan city) using an ultraviolet lamps in 2018-2019. We used BLBT5/4W Ultraviolet Black Light Bulb with 2-3 hours of exposure from May 27 to October 13, 2018 and FLU10 T8 G13/18W with 2-13 hours of exposure from March 31 to October 10, 2019. Second author collected the majority of examined specimens; all specimens are deposited in collection of the Papanin Institute for Biology of Inland Waters of the Russian Academy of Sciences.
\end{abstract}

\section{Keywords}

Augyles, Coleoptera, Eastern Siberia, new records, Heterocerus, Heteroceridae, Russia

Copyright Alexey S. Sazhnev, Sergey V. Dragan. This is an open access article distributed under the terms of the Creative Commons Attribution License (CC BY 4.0), which permits unrestricted use, distribution, and reproduction in any medium, provided the original author and source are credited. 


\section{Introduction}

The variegated mud-loving beetles (Heteroceridae) is a small family of Coleoptera belonging to the superfamily Byrrhoidea. Family Heteroceridae includes 5 genera (King et al. 2011) and 349 recent species (authors data). Adults and larvae inhabit the banks of various water bodies along the narrow ground strip at water edge, where they build tunnels in sand or other wet substrates. The imago often flies towards light at night.

According to modern catalogues and articles, the fauna of Heteroceridae in Russia comprises 22 species of two genera (Mascagni 2006, 2016; Sazhnev 2016; Sazhnev and Kozminykh 2019). The fauna and distribution of the family in Siberia is still not well studied and the available data are presented in old faunistic papers (Gebler 1830; Sahlberg 1880; Heyden 1880, 1881; Zaitzev 1908; Jakobson 1913).

In recent publications, the information about Heteroceridae species (for Siberia) is available in articles dedicated to arthropods inhabited salty soils in the south of Siberia (Mordkovich and Volkovintser 1965; Mordkovich and Lyubechanskii 2017) and some specialized faunistic papers (Kirejtshuk 2001; Efimov and Litovkin 2015; Sazhnev 2016, 2018a, 2018b). In the second edition of the Catalogue of Palaearctic Coleoptera (Mascagni 2016), Augyles flavidus (Rossi 1794) was reported for Siberia and the Far East; however, these recording are erroneous. Augyles flavidus is distributed in Mediterranean, North Africa, Transcaucasia, south of European part of Russia, western Central Asia, and not found in Siberia.

There are ten species of the Heteroceridae, which have been recorded for the fauna of Siberia (Strien 1980; Mascagni 2006; Sazhnev 2016; Efimov and Litovkin 2015), but only one species Heterocerus parallelus Gebler, 1830 was recorded in the southern Khakassia (Mordkovich and Volkovintser, 1965).

\section{Material and methods}

The variegated mud-loving beetles were collected in the upper part of the Yenisei River basin (Republic of Khakassia, Abakan city, Abakan River valley, Figs 1,2) by means of BLB-T5/4W Ultraviolet Black Light Bulb with 2-3 hours of exposure in May 27-October 13, 2018 and FLU10 T8 G13/18W with 2013 hours of exposure in March 31-October 10, 2019. The material was stored in 95\% ethanol or alcoholformalin.

Second author collected the majority of examined specimens; all specimens are deposited in collection of the Papanin Institute for Biology of Inland Waters of the Russian Academy of Sciences (IBIW, Borok, Yaroslavl Region, Russia; depository and collector not listed in the text). Map was created in SimpleMappr online service (www.simplemappr.net). 


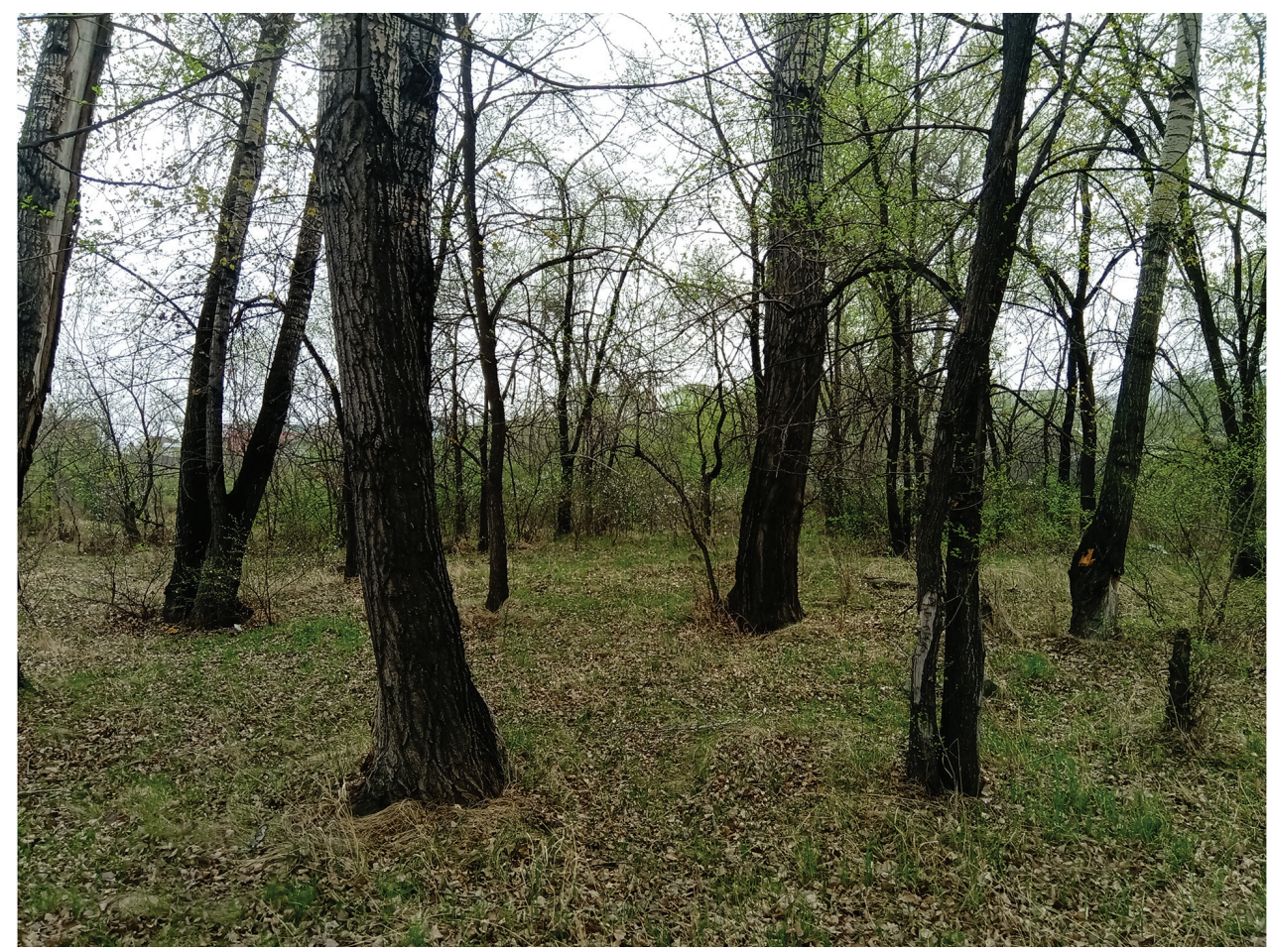

Figure I. Collecting site of the variegated mud-loving beetles in the Abakan River valley (Abakan city, 5342'49.5"N, 91³0'19.6"E).

\section{Taxonomy}

\section{Family Heteroceridae Macleay, 1825}

\section{Genus Augyles Schiødte, 1866}

\section{Augyles interspidulus (Charpentier, 1979)}

Material examined. RUSSIA - 2 males; Republic of Khakassia, Abakan, Abakan River valley; 534' $49.5^{\prime \prime} \mathrm{N}, 91^{\circ} 30^{\prime} 19.6^{\prime \prime E} ; 22$ June 2018 - 3 males, 5 females; same locality; 24 June 2018 • 2 males, 1 female with 42 eggs; same locality; 28 June 2018 - 1 female; same locality; 29 June 2018 1 male; same locality; 29-30 June 2018; at night $\bullet 3$ females; same locality; 30 June 2018 • 4 males, 8 females; same locality; 1 July 2018 • 6 males, 3 females; same locality; 2 July 2018 • 4 males, 4 females; same locality; 3 July 2018 - 2 females; same locality; 4-05 June 2019; 22:00-1:00 hours • 1 female; same locality; 15 June 2019; 21:00-00:00 hours $\bullet 2$ females; same locality; 18-19 June 2019 • 2 males, 3 females; same locality; 25 June 2019; 22:00-00:00 hours -2 females; same locality; 28-29 June 2019; 22:00-6:00 hours $\bullet 4$ males, 2 females; same locality; 6-7 July 2019; 21:00-1:00 hours $\bullet 1$ male; same locality; 7-8 


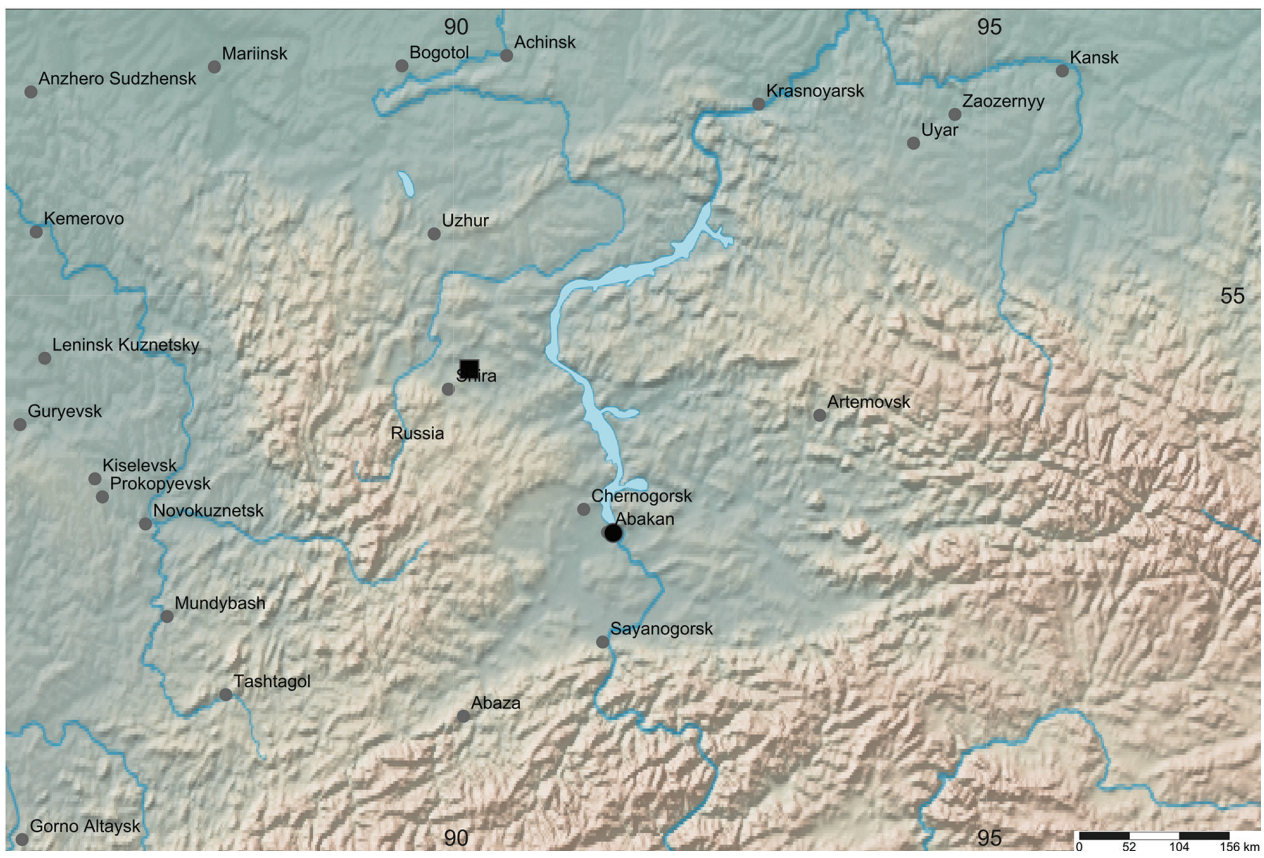

Figure 2. Sampling localities: squares - Shirinsky distr., Belyo Lake; circles - Abakan, Abakan River valley.

July 2019; 21:00-3:00 hours • 1 female; same locality; 8-9 July 2019; 21:00-1:00 • 1 male, 1 female; same locality; 22-23 July 2019; 21:00-7:00 hours $\bullet 1$ female; same locality; 27-28 Aug. 2019; 20:00-7:00 hours.

Distribution. The species is known from Asia: China (Shaanxi) (Mascagni 2003), Mongolia (Charpentier 1979; Mascagni 2006, 2016; Prokin et al. 2020), Russia (south of Eastern Siberia) (Sazhnev 2016, 2018a). The species is recorded for the Republic of Khakassia for the first time.

\section{Genus Heterocerus Fabricius, 1792}

\section{Heterocerus fenestratus (Thunberg, 1784)}

Material examined. RUSSIA • 1 female; Republic of Khakassia, Abakan, Abakan River valley; $53^{\circ} 42^{\prime} 49.5^{\prime \prime} \mathrm{N}, 91^{\circ} 30^{\prime} 19.6^{\prime \prime} \mathrm{E} \bullet 1$ female; same locality; 15 June 2019; 21:00-00:00 hours $\bullet 1$ female; same locality; 20 June 2019; 20:00-00:00 hours • 1 female; same locality; 29-30 June 2019 • 2 males, 2 females; same locality; 6-7 July 2019; 21:00-1:00 hours 1 female; 7-8 July 2019; 21:00-3:00 hours $\bullet 1$ male; same locality; 8-9 July 2019; 21:00-1:00 hours 11 female; same locality; $13-14$ July 2019; 21:00-6:00 hours $\bullet 1$ female; same locality; $20-21$ July $2019 ; 21: 00-6: 00$ hours $\bullet 1$ 
male, 1 female; same locality; 22-23 July 2019; 22:00-4:00 hours $\bullet 2$ females; same locality; 27-28 July 2019; 22:00-7:00 hours 1 female; same locality; 28 July 2019; 22:00-23:00 hours $\bullet 2$ females; same locality; 29-30 July 2019; 21:00-7:00 hours • 1 female; same locality; 4-5 Aug. 2019; 22:00-8:00 hours.

Distribution. It is a widespread Holarctic species, also known from the Oriental region: Laos, Philippines, Thailand, Vietnam (Charpentier 1979; Mascagni 2003, 2006, 2016; King and Lago 2012) and the Southern Hemisphere (Chile) (Sazhnev 2019). The species is recorded for the Republic of Khakassia for the first time.

\section{Heterocerus fossor Kiesenwetter, 1843}

Material examined. RUSSIA • 1 male; Republic of Khakassia, Abakan, Abakan River valley; 53² $42^{\prime} 49.5^{\prime \prime} \mathrm{N}, 91^{\circ} 30^{\prime} 19.6^{\prime \prime} \mathrm{E}$; 24 June 2018 • 1 female; same locality; 30 June 2018 - 1 female; same locality; 12 June 2019 • 2 females; same locality; 27-28 July 2019; 22:00-7:00 hours 1 male; same locality; 27-28 Aug. 2019; 20:00-7:00 hours.

Distribution. This species distributed in Europe, Turkey, Iran, Kazakhstan, Tajikistan, southern part of Western and Eastern Siberia (Mascagni 2006, 2016). The species is recorded for the Republic of Khakassia for the first time.

\section{Heterocerus fusculus fusculus Kiesenwetter, 1843}

Material examined. RUSSIA - 1 male; Republic of Khakassia, Abakan, Abakan River valley; 5342'49.5"N 9130'19.6"E; 30 June 2018 • 1 male; same locality; 2 July 2018.

Distribution. The species is known from Europe, Turkey, Iran, Central Asia (Kazakhstan, Kyrgyzstan, Turkmenistan, Uzbekistan), south of Siberia to Cisbaikalia (Mascagni 2006, 2016; Prokin et al. 2016; Litovkin and Sazhnev 2018). The species is recorded for the Republic of Khakassia for the first time.

\section{Heterocerus obsoletus Curtis, 1828}

Material examined. RUSSIA • 1 female; Republic of Khakassia, Abakan, Abakan Riv-

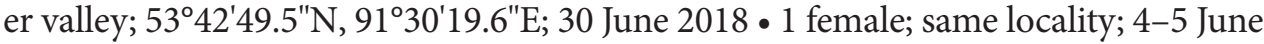
2019; 22:00-1:00 hours 1 female; same locality; 7-8 July 2019; 21:00-3:00 hours.

Distribution. It is known from Europe, Southwest (partly) and Iran, Central Asia (Kazakhstan, Kyrgyzstan, Tajikistan, Uzbekistan), Mongolia, south of Western and Eastern Siberia (Zaitzev 1908; Charpentier 1979; Strien 1980; Mascagni 2003, 2006, 2016; Efimov and Litovkin 2015; Prokin et al. 2016; Litovkin and Sazhnev 2018; Prokin et al. 2020). The species is recorded for the Republic of Khakassia for the first time. 


\section{Heterocerus parallelus Gebler, 1830}

Material examined. RUSSIA 1 male, 3 females; Republic of Khakassia, Shirinsky distr., Belyo Lake (Fig. 2); 5439'00.0"N, 90¹0'48.0"E; $382 \mathrm{~m}$ a.s.l.; 1-3 July 2011; K. Tomkovich leg.; IBIW; «yellow plates» 1 male; Abakan, Abakan River valley; $53^{\circ} 42^{\prime} 49.5^{\prime \prime} \mathrm{N}, 91^{\circ} 30^{\prime} 19.6^{\prime \prime E}$; $19-20$ July 2019; 22:00-2:00 hours.

Distribution. This species distributed in the southern part of Europe, Turkey, Iran, Lebanon, Kazakhstan, Kyrgyzstan, Tajikistan, Turkmenistan, Mongolia, south of Western and Eastern Siberia (Zaitsev 1946; Mascagni 2006, 2016; Litovkin and Sazhnev 2018; Prokin et al. 2020). The species was known from the southern part of the Republic of Khakassia (Mordkovich and Volkovintzer 1965).

\section{Acknowledgements}

A. Sazhnev was partially supported by the Russian State Assignment (aaaaa18-118012690105-0). The authors declare no competing interests.

\section{References}

Charpentier R (1979) Heteroceridae (Coleoptera) from Mongolia with description of Heterocerus kaszabi n. sp. and Heterocerus interspidulus n. sp. Entomologica scandinavica 10(3): 229-237.

Efimov DA, Litovkin SV (2015) New data on the fauna of Heteroceridae (Coleoptera) of Western Siberia. Baltic Journal of Coleopterology 15(1): 29-35.

Gebler FA (1830) Bemerkungen über die Insekten Sibiriens, vorzüglich des Altai. [Part 3]. Ledebour C.F. (ed.). Reise durch das Altai-Gebirge und die soongorische KirgisenSteppe. Zweiter Theil. Berlin, G. Reimer, pp. 1-228.

Heyden L (1880-1881) Catalog den Coleopteren von Sibirien mit Einschluss derjenigen der Turanischen Länder, Turkestans und der chinensischen Grenzgebiete. Deutschen Entomologischen Gesellschaft. XXIV. Berlin, pp. 224.

Jacobson GG (1913) Semeystvo Heteroceridae. Pilousy. Zhuki Rossii i zapadnoy Evropy. Rukovodstvo k opredeleniyu zhukov. Vol. 10. A.F. Davrien, Sankt-Peterburg, pp. 867-869. [in Russian, English translation in: Family Heteroceridae. Mud-loving beetles. In: Beetles of Russia, Western Europe and neighbouring countries. Guide to the determination of beetles. Vol. 10. A.F. Devrien, St.-Petersburg, pp. 867-869].

King JG, Lago PK (2012) The variegated mudloving beetles (Coleoptera: Heteroceridae) of Missisippi and Alabama, with discussion and keys to the species occurring in the southeastern United States. Insecta Mundi 275: 1-53.

King JG, Starr JR, Lago PK (2011) Molecular data resolves relationships within Heteroceridae (Dryopoidea: Coleoptera). Systematic Entomology 36: 435-445. doi:10.1111/j.13653113.2011.00571.x 
Kirejtshuk AG (2001) Family Heteroceridae. In: Tsalolikhin S.J. (ed.). Key to freshwater invertebrates of Russia and adjacent lands. Vol.5. St.Petersburg. Nauka, pp. 341-348. [in Russian]

Litovkin SV, Sazhnev AS (2018) The variegated mud-loving beetles (Coleoptera: Heteroceridae) of Kyrgyzstan. Far Eastern Entomologist 372: 25-32. doi.org/10.25221/fee.372.2

Mascagni A (2003) Descriptions of three new species, and updated checklist of the Heteroceridae of China and neighbouring countries (Coleoptera: Heteroceridae). Koleopterologische Rundschau 73: 285-296.

Mascagni A (2006) Heteroceridae. In: Löbl, I. \& Smetana, A. (Eds.), Catalogue of Palaearctic Coleoptera. Vol. 3. Apollo Books, Stenstrup, pp. 446-449.

Mascagni A (2016) Heteroceridae. In: Löbl, I. \& Löbl, D. (Eds.), Catalogue of Palaearctic Coleoptera. Vol. 3. Revised and Updated Edition. Brill, Leiden, pp. 610-616.

Mordkovich VG, Volkovintser VV (1965) Animal population of soils of salt lake shores in the south Khakassia and Tuva. Zoologichesky zhurnal 44(12): 1747-1760. [in Russian; abstract in English]

Mordkovich, VG, Lyubechanskii II (2017) The Role of Large Arthropods in the Development of Halomorphic Soils in the South of Siberia. Eurasian Soil Science 50(6): 688700. doi: 10.1134/S1064229317040068

Prokin AA, Chuluunbaatar G, Angus RB, Jäch MA, Petrov PN, Ryndevich SK, Byambanyam E, Sazhnev AS, Shaverdo H (2020) New records of water beetles (Coleoptera: Gyrinidae, Haliplidae, Noteridae, Dytiscidae, Helophoridae, Hydrophilidae, Hydraenidae) and shore beetles (Coleoptera: Heteroceridae) of Mongolia. Aquatic Insects 41(1): 1-44. doi: 10.1080/01650424.2019.1651870

Prokin AA, Sazhnev AS, Kovalenko YaN (2016) New records of water beetles from families Helophoridae, Hydrophilidae and Heteroceridae (Coleoptera) from Uzbekistan. Caucasian entomological bulletin 12(1): 69-70.

Sahlberg JR (1880) Bidrag till nordvestra Sibiriens Insektfauna. Coleoptera. Insamlade under expeditionerna till Obi och Jenessej 1876 och 1877. I. Cicindelidae, Carabidae, Dytiscidae, Hydrophilidae, Gyrinidae, Dryopidae, Georyssidae, Limnichidae, Heteroceridae, Staphylinidae och Micropeplidae. Kungl. Svenska Vetenskaps Akademiens Handlingar 17(4): 1-115.

Sazhnev AS (2016) Species of heterocerid beetles (Coleoptera: Heteroceridae) new to Russia, Eversmannia. 47-48: 104. [in Russian; abstract in English]

Sazhnev AS (2018a) Distribution of three Augyles species of the «cribratellus» species group (Coleoptera: Heteroceridae) in the territories of Russia and neighboring countries. Euroasian Entomological Journal 17(3): 182-185. doi: 10.15298/euroasentj.17.3.06 [in Russian; abstract in English]

Sazhnev AS (2018b) Materials to the variegated mud-loving beetles fauna (Coleoptera: Heteroceridae) of the Russian Far East. Caucasian Entomological Bulletin 14(2): 153-155. doi: 10.23885/181433262018142-153155 [in Russian; abstract in English]

Sazhnev AS (2019) A new synonymy of the species Heterocerus fenestratus (Thunberg, 1784) (Coleoptera: Heteroceridae) and his first records for South Hemisphere. Zootaxa 4624(4): 589-592. https://doi.org/10.11646/zootaxa.4624.4.10 
Sazhnev AS, Kozminykh VO (2019) Zhestkokrylye semejstva Heteroceridae (Insecta: Coleoptera) v faune Urala. Materialy po flore i faune Respubliki Bashkortostan 22: 88-105 [in Russian, English translation in: The beetles of the family Heteroceridae (Insecta: Coleoptera) in the fauna of the Urals. Materials on the flora and fauna of the Republic of Bashkortostan 22: 88-105].

Strien AJ (1980) De Nederlandse soorten van de keverfamilie Heteroceridae. Zoologische Bijdragen 27: 9-42.

Zaitzev PhA (1908) Catalogue des Coléoptères aquatiques des familles des Dryopidae, Georyssidae, Cyathoceridae, Heteroceridae et Hydrophilidae. Horae Societatis Entomologicae Rossicae 38(4): 283-420.

Zaitsev FA (1946) [Distribution in Transcaucasia species of the variegated mud-loving beetles (Coleoptera, Heteroceridae)]// Trudy Zoologicheskogo instituta AN GruzSSR 6: 213-220. [In Russian] 